\title{
Vegetable and Fruits Consumption, Physical Activity, and Nutritional Status of Adolescents
}

\author{
Konsumsi Sayur dan Buah, Aktivitas Fisik, dan Status Gizi Remaja
}

\author{
Nanda R. Heratama*1 ${ }^{1}$, Kusnandar Kusnandar ${ }^{2}$, Suminah Suminah ${ }^{3}$ \\ ${ }^{1}$ Bagian Ilmu Gizi, Universitas Sebelas Maret, Surakarta \\ ${ }^{2}$ Bagian Agribisnis, Universitas Sebelas Maret, Surakarta \\ ${ }^{3}$ Bagian Penyuluhan dan Komunikasi Pertanian, Universitas Sebelas Maret, Surakarta
}

DOI: 10.24252/al-sihah.v13i2.23588

Received: 8 September 2021 / In Reviewed: 13 December 2021 / Accepted: 27 December 2021 / Available online: 30 December 2021 (C) The Authors 2021. This is an open access article under the CC BY-NC-SA 4.0 license

\begin{abstract}
The nutritional status of adolescents is one of the main challenges for health workers and the community. This study analyzed the relationship between vegetable consumption habits and physical activity with the nutritional status of adolescents. The research design used was cross-sectional. The sampling technique was carried out using the proportional random sampling method. The population in this study were teenagers in Pangkalpinang City. The sample consisted of 340 teenagers in the city of Pangkalpinang. The prevalence of malnutrition in adolescents is 38.2 with the prevalence of over and undernutrition being $31.2 \%$ and $7 \%$, respectively. Most teenagers with good nutritional status (67.3\%) have the habit of consuming vegetables frequently. The results of logistic regression analysis showed that the habit of consuming vegetables and physical activity had an effect on the nutritional status of adolescents. The risk of malnutrition increased significantly by 2.46 times in adolescents with less physical activity $(p=0.016)$ and increased by 1.94 times in adolescents with less vegetable consumption habits $(p=$ 0.005). The community, especially adolescent families, needs to receive education about the importance of healthy habits such as the consumption of vegetables and fruit to maintain good nutritional status in adolescents.
\end{abstract}

\begin{abstract}
ABSTRAK
Status gizi remaja merupakan salah satu tantangan utama bagi tenaga kesehatan dan masyarakat. Penelitian ini menganalisis hubungan kebiasaan konsumsi sayur dan aktivitas fisik dengan status gizi remaja. Desain penelitian yang digunakan adalah cross sectional. Teknik pengambilan sampel dilakukan dengan metode proportional random sampling Populasi dalam penelitian ini adalah remaja di Kota Pangkalpinang. Sampel terdiri dari 340 remaja di kota Pangkalpinang. Prevalensi malnutrisi pada remaja sebesar 38.2 dengan prevalensi gizi lebih dan kurang masing-masing $31.2 \%$ dan $7 \%$. Sebagian besar remaja dengan status gizi baik (67.3\%) memiliki kebiasaan konsumsi sayur sering. Hasil analisis regresi logistik menunjukkan bahwa kebiasaan konsumsi sayur dan aktivitas fisik berpengaruh terhadap status gizi remaja. Risiko malnutrisi meningkat secara signifikan sebesar 2.46 kali pada remaja dengan aktivitas fisik kurang $(p=0.016)$ dan meningkat sebesar 1.94 kali pada remaja dengan kebiasaan konsumsi sayur yang kurang $(\mathrm{p}=0.005)$. Masyarakat khususnya keluarga remaja perlu mendapat edukasi tentang pentingnya kebiasaan yang sehat seperti konsumsi sayur dan buah untuk mempertahankan status gizi baik pada remaja.
\end{abstract}

\section{GRAPHICAL ABSTRACT}

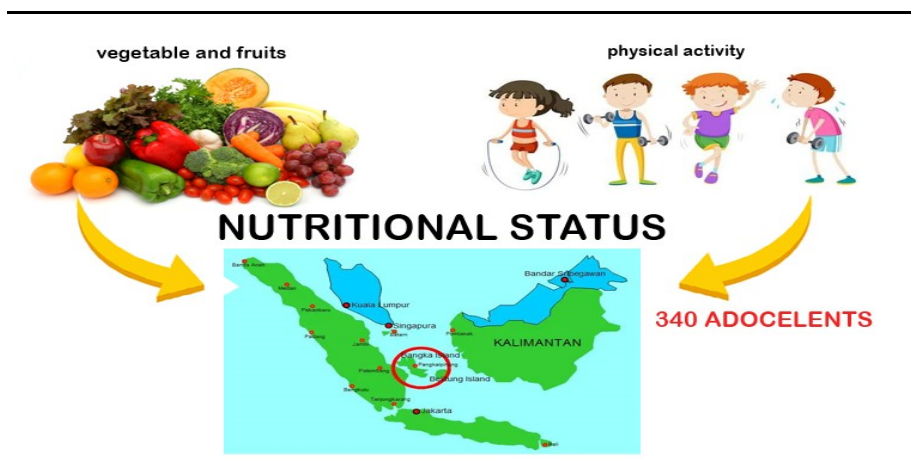

Keyword

adolescents nutrition; consumption of vegetables and fruits; nutritional status; physical activity

Kata Kunci:

aktivitas fisik; konsumsi sayur dan buah; gizi remaja; status gizi

* Correspondence

Perum. Puri Reana II No. 75, Jl. Mentawai 1 Desa

Damai Air Pengabis, Sungailiat, Bangka Belitung

Email: nandafayzaa@gmail.com 


\section{PENDAHULUAN}

Obesitas merupakan salah satu faktor penentu mortalitas dan morbiditas. World Health Organization (2016) menyatakan bahwa kelebihan berat badan dan obesitas menempati peringkat kelima teratas dari risiko kematian global. Setidaknya 2,8 juta orang dewasa meninggal setiap tahun karena kelebihan berat badan dan obesitas (Hussaun et al., 2020). Berdasarkan data Riset Kesehatan Dasar (Riskesdas) 2013, prevalensi obesitas remaja di Indonesia menurut kelompok usia 16-18 tahun adalah 7,3\%. Pada tahun 2018, prevalensi remaja overweight sebesar $13,5 \%$, dengan status gizi gemuk 9,5\% dan obesitas 4\%. Selain itu, Indonesia juga tercatat memiliki prevalensi asupan sayur dan buah yang kurang memadai. Konsumsi buah dan sayur Indonesia pada kelompok umur 15-19 tahun hanya 3,6\% dan di Bangka Belitung hanya 2,9\%. Bangka Belitung juga memiliki prevalensi obesitas remaja tertinggi kedua menurut provinsi setelah DKI Jakarta, yaitu $6,3 \%$ dan gemuk 9,1\%. Hasil penelitian pada remaja di Kota Pangkalpinang, terdapat 6\% remaja mengalami kegemukan (Emilia \& Cilmiyati, 2016).

Status gizi dipengaruhi oleh faktor lain seperti perilaku sedentary dan aktivitas fisik yang rendah, peningkatan konsumsi makanan berkalori tinggi dan minuman tinggi gula (Camilo et al., 2018; Abizanda et al., 2015; Kordas et al., 2018). Anakanak dan remaja yang memiliki tingkat aktivitas fisik yang rendah lebih berisiko mengalami kelebihan berat badan atau obesitas dan memiliki risiko tinggi lingkar pinggang yang lebih besar (Mead et al., 2017).
Dukungan keluarga berperan penting dalam membentuk perilaku diet dan aktivitas fisik remaja (Hargreaves et al., 2021). Dukungan keluarga dikaitkan dengan peningkatan aktivitas fisik (Lenne et al., 2019). Dukungan keluarga juga berkontribusi terhadap peningkatan status gizi normal pada remaja (Schwarzenberg et al., 2018).

Penelitian sebelumnya oleh Kurdanti et al (2015) didapati hasil bahwa remaja dengan aktivitas fisik tidak aktif berisiko lebih terhadap terjadinya obesitas. Penelitian tersebut lebih menekankan pada konsumsi makanan cepat saji (fast food) dan menggunakan obesitas sebagai variabel terikat. Penelitian oleh Emilia \& Cilmiyati (2016) yang didasari jumlah remaja obesitas di Kota Pangkalpinang, dengan desain case control, melihat pengaruh konseling dan aktivitas terhadap penurunan berat badan. Berbeda dengan penelitian diatas, penelitian ini menjadikan remaja dengan semua kriteria status gizi sebagai sampel, usia dibatasi 16-18 tahun dan melihat hubungan langsung dari beberapa variabel secara serentak dengan status gizi. Penelitian ini bertujuan untuk menganalisis hubungan kebiasaan konsumsi buah dan sayur serta asupan zat gizi, aktivitas fisik dan dukungan keluarga dengan status gizi remaja usia 16-18 tahun.

\section{METODE PENELITIAN}

Penelitian ini menggunakan desain cross sectional dengan jenis observasional analitik. Populasi dalam penelitian ini adalah semua remaja di Kota Pangkalpinang. Sampel terdiri dari 340 remaja di Kota Pangkal Pinang, yang diambil secara proporsional random sampling, yang telah 
Tabel 1

Karakteristik Responden

\begin{tabular}{|c|c|c|}
\hline Karakteristik & $\mathrm{n}$ & $\%$ \\
\hline \multicolumn{3}{|l|}{ Jenis Kelamin } \\
\hline Laki-laki & 105 & 30.9 \\
\hline Perempuan & 235 & 69.1 \\
\hline \multicolumn{3}{|l|}{ Usia } \\
\hline 16 tahun & 307 & 90.3 \\
\hline 17 tahun & 21 & 6.2 \\
\hline 18 tahun & 12 & 3.5 \\
\hline \multicolumn{3}{|l|}{ Ketersediaan Sayuran } \\
\hline Tersedia setiap hari & 72 & 21.1 \\
\hline Tersedia 3-6 hari/minggu & 105 & 30.9 \\
\hline Tidak tersedia setiap hari & 163 & 48 \\
\hline \multicolumn{3}{|l|}{ Ketersediaan Buah-buahan } \\
\hline Tersedia setiap hari & 178 & 52.4 \\
\hline Tersedia 3-6 hari/minggu & 47 & 13.8 \\
\hline Tidak tersedia setiap hari & 115 & 33.8 \\
\hline
\end{tabular}

mengisi e form. Kriteria inklusi, meliputi : remaja berusia 16-18 tahun, tinggal bersama orang tua, remaja tidak memiliki riwayat sakit selama 3 bulan terakhir dan bersedia menjadi responden. Sedangkan kriteria eksklusinya adalah sebagai berikut : remaja yang mengonsumsi obatobatan yang dapat mempengaruhi tinggi dan berat badan, mengikuti semua kegiatan penelitian, remaja yang menderita penyakit yang memerlukan diet tertentu (diabetes, ginjal, penyakit jantung, kanker, hipertensi) dan sedang menjalankan diet untuk menurunkan atau menambah berat badan.

Variabel terikat dalam penelitian ini adalah status gizi remaja. Responden yang memenuhi kriteria inklusi diberikan penjelasan tentang tujuan dan prosedur penelitian serta mengisi persetujuan melalui e-form. Pengumpulan data dukungan keluarga menggunakan kuesioner dukungan keluarga. Asupan gizi dan kebia- saan konsumsi sayur dan buah menggunakan metode recall $2 \times 24$ jam tidak berurutan dan kuesioner FFsQ. Pengambilan data aktivitas fisik menggunakan kuesioner aktivitas fisik.

Protokol penelitian ini telah disetujui oleh Komite Etik Universitas Sebelas Maret Surakarta melalui Surat Keputusan Nomor 072 / UN27.06.6.1 / KEPK / EC / 2020. Dalam penelitian ini, data diperoleh dan dianalisis dengan menggunakan SPSS Versi 16. Data Hasil penelitian selanjutnya dilakukan uji Chi Square dan uji Regresi Logistik untuk mengetahui hubungan konsumsi sayur dan buah, asupan gizi dan dukungan keluarga dengan status gizi remaja.

\section{HASIL PENELITIAN}

Subyek yang diteliti sebanyak 340 remaja. Karakteristik subjek penelitian dapat dilihat pada Tabel 1, dimana sebesar $69,1 \%$ responden adalah perempuan, dan 
Tabel 2

Distribusi Frekuensi Variabel

\begin{tabular}{|c|c|c|c|}
\hline Variabel & Kategori & Jumlah & Persentase \\
\hline \multicolumn{4}{|l|}{ Status Gizi (IMT/U) : } \\
\hline Z skor $>1 \mathrm{SD}$ & Malnutrisi & 106 & 31.2 \\
\hline Z skor $-2 \mathrm{SD}$ s/d $1 \mathrm{SD}$ & Nutrisi baik & 210 & 61.8 \\
\hline Z skor $<-2$ SD & Malnutrisi & 24 & 7 \\
\hline \multicolumn{4}{|l|}{ Kebiasaan mengkonsumsi sayur: } \\
\hline$\geq 5 \mathrm{kali} / \mathrm{minggu}$ & Sering & 226 & 66.5 \\
\hline$<5 \mathrm{kali} /$ minggu & Jarang & 114 & 33.5 \\
\hline \multicolumn{4}{|l|}{ Kebiasaan mengkonsumsi buah: } \\
\hline$\geq 5 \mathrm{kali} / \mathrm{minggu}$ & Sering & 241 & 70.9 \\
\hline$<5 \mathrm{kali} /$ minggu & Jarang & 99 & 29.1 \\
\hline \multicolumn{4}{|l|}{ Asupan Karbohidrat } \\
\hline$>80 \% \mathrm{AKG}$ & Cukup & 312 & 91.8 \\
\hline$<80 \% \mathrm{AKG}$ & Rendah & 28 & 8.2 \\
\hline \multicolumn{4}{|l|}{ Asupan protein } \\
\hline$>80 \% \mathrm{AKG}$ & Cukup & 9 & 2.6 \\
\hline$<80 \% \mathrm{AKG}$ & Rendah & 331 & 97.4 \\
\hline \multicolumn{4}{|l|}{ Asupan lemak } \\
\hline$>80 \% \mathrm{AKG}$ & Cukup & 87 & 25.6 \\
\hline$<80 \% \mathrm{AKG}$ & Rendah & 253 & 74.4 \\
\hline \multicolumn{4}{|l|}{ Asupan serat } \\
\hline$>80 \% \mathrm{AKG}$ & Cukup & 9 & 2.6 \\
\hline$<80 \% \mathrm{AKG}$ & Rendah & 331 & 97.4 \\
\hline \multicolumn{4}{|l|}{ Aktivitas fisik } \\
\hline MET $<600$ menit & Rendah & 154 & 45.3 \\
\hline MET min 600menit & Sedang & 152 & 44.7 \\
\hline MET $\geq 1500$ menit & Tinggi & 34 & 10 \\
\hline \multicolumn{4}{|l|}{ Dukungan keluarga } \\
\hline$X<\operatorname{Median}(57)$ & Rendah & 279 & 82.1 \\
\hline$X \geq \operatorname{Median}(57)$ & Tinggi & 61 & 17.9 \\
\hline
\end{tabular}

sebagian besar subjek $(90,3 \%)$ berusia 16 tahun. Ketersediaan sayuran dari responden penelitian yaitu sebanyak 163 responden $(48,0 \%)$ menyatakan tidak ada sayuran yang tersedia setiap hari. Di sisi lain, sebagian besar responden menyatakan bahwa buahbuahan tersedia setiap hari $(52,4 \%)$.

Tabel 2 menunjukkan bahwa sebagian besar remaja SMA sederajat di kota Pangkal Pinang memiliki gizi baik $(61,8 \%)$ dan sering mengkonsumsi sayur dan buah ( 5 kali/minggu) sebesar $66,5 \%$ dan $70,9 \%$. Sebagian besar responden memiliki asupan karbohidrat yang cukup (91,8\%), namun hampir semua responden kurang asupan lemak $(74,4 \%)$, protein $(97,4 \%)$ dan serat $(97,4 \%), 154$ remaja memiliki aktivitas fisik yang rendah $(45,3 \%)$. ) dan dukungan keluarga rendah $(82,1 \%)$.

Analisis bivariat dilakukan untuk mengetahui ada tidaknya hubungan antara variabel bebas kebiasaan konsumsi sayur dan buah, asupan gizi, aktivitas fisik dan dukungan keluarga dengan variabel terikat status gizi, menggunakan uji chi-square. Hasil analisis bivariat tersebut dilampirkan pada Tabel 3, yang menunjukkan bahwa responden yang sering mengkonsumsi sayur 
Tabel 3

Analisis Hubungan Varibel-Variabel dengan Status Gizi

\begin{tabular}{|c|c|c|c|c|c|c|c|c|}
\hline \multirow{3}{*}{ Kategori } & \multicolumn{4}{|c|}{ Status Gizi } & \multirow{2}{*}{\multicolumn{2}{|c|}{ Total }} & \multirow{3}{*}{ OR } & \multirow{3}{*}{$p-$} \\
\hline & \multicolumn{2}{|c|}{ Status Gizi Baik } & \multicolumn{2}{|c|}{ Malnutrisi } & & & & \\
\hline & $\mathrm{n}$ & $\%$ & $\mathrm{n}$ & $\%$ & $\mathrm{n}$ & $\%$ & & \\
\hline \multicolumn{9}{|c|}{ Kebiasaan Konsumsi Sayur } \\
\hline Sering & 152 & 67.3 & 74 & 32.7 & 226 & 100 & 1.938 & 0.005 \\
\hline Jarang & 58 & 50.9 & 56 & 49.1 & 114 & 100 & & \\
\hline \multicolumn{9}{|c|}{ Kebiasaan Konsumsi Buah } \\
\hline Sering & 144 & 59.8 & 97 & 40.2 & 241 & 100 & 0.742 & 0.285 \\
\hline Jarang & 66 & 66.7 & 33 & 33.3 & 99 & 100 & & \\
\hline \multicolumn{9}{|l|}{ Asupan Karbohidrat } \\
\hline Cukup & 197 & 63.1 & 115 & 36.9 & 312 & 100 & 1.977 & 0.123 \\
\hline Rendah & 13 & 46.4 & 15 & 53.6 & 28 & 100 & & \\
\hline \multicolumn{9}{|l|}{ Asupan Protein } \\
\hline Cukup & 7 & 77.8 & 2 & 22.2 & 9 & 100 & 2.207 & 0.513 \\
\hline Rendah & 203 & 61.3 & 128 & 38.7 & 331 & 100 & & \\
\hline \multicolumn{9}{|l|}{ Asupan Lemak } \\
\hline Cukup & 59 & 67.8 & 28 & 32.2 & 87 & 100 & 1.423 & 0.223 \\
\hline Rendah & 151 & 59.7 & 102 & 40.3 & 253 & 100 & & \\
\hline \multicolumn{9}{|l|}{ Asupan Serat } \\
\hline Cukup & 4 & 44.4 & 5 & 55.6 & 9 & 100 & 0.485 & 0.462 \\
\hline Rendah & 206 & 62.2 & 125 & 37.8 & 331 & 100 & & \\
\hline \multicolumn{9}{|l|}{ Asupan Energi } \\
\hline Cukup & 149 & 61.8 & 92 & 38.2 & 241 & 100 & 1.009 & 1 \\
\hline Rendah & 61 & 61.6 & 38 & 38.4 & 99 & 100 & & \\
\hline \multicolumn{9}{|l|}{ Aktivitas Fisik } \\
\hline Sedang & 196 & 64.1 & 110 & 35.9 & 306 & 100 & 2.545 & 0.016 \\
\hline Tinggi & 14 & 41.2 & 20 & 58.8 & 34 & 100 & & \\
\hline \multicolumn{9}{|l|}{ Dukungan Keluarga } \\
\hline Tinggi & 40 & 65.6 & 21 & 34.4 & 61 & 100 & 1.221 & 0.596 \\
\hline Rendah & 170 & 60.9 & 109 & 39.1 & 279 & 100 & & \\
\hline
\end{tabular}

dan buah cenderung memiliki status gizi yang baik. Sebanyak 152 responden $(67,3 \%)$ dengan sering konsumsi sayur dan 144 responden $(59,8 \%)$ dengan sering konsumsi buah memiliki status gizi baik.

Hasil uji chi-square diperoleh nilai $p$ value 0,005 yang berarti terdapat hubungan yang signifikan antara kebiasaan konsumsi sayur dengan status gizi. Data asupan gizi menunjukkan bahwa hampir semua responden memiliki asupan karbohidrat yang cukup, namun asupan protein, lemak dan serat tergolong kurang.
Hasil uji bivariat diperoleh $\mathrm{p}>0,05$ yang berarti pada penelitian ini tidak terdapat hubungan yang bermakna antara asupan gizi dengan status gizi.

Tabel 3 juga menunjukkan bahwa responden dengan aktivitas fisik minimal $600 \mathrm{MET}$ menit/minggu berpeluang memiliki status gizi baik. Sebanyak 196 responden $(64,1 \%)$ dengan aktivitas fisik sedang memiliki status gizi baik. Hasil uji chi -square pada penelitian ini diperoleh nilai $\mathrm{p}$ value sebesar 0,016 yang berarti terdapat hubungan yang signifikan antara variabel 
Tabel 4

Langkah Pemodelan Analisis Multivariat

\begin{tabular}{lcccccc}
\hline \multicolumn{1}{c}{ Variabel } & OR1 & p-value1 & OR2 & p-value2 & OR3 & p-value3 \\
\hline Konsumsi sayuran & 1,892 & 0,008 & 1,889 & 0,008 & 1,946 & 0,005 \\
Asupan karbohidrat & 1,635 & 0,230 & 1,738 & 0,175 & - & - \\
Asupan lemak & 1,358 & 0,259 & - & - & - & - \\
Aktivitas fisik & 2,421 & 0,018 & 2.427 & 0.018 & 2.461 & 0.016 \\
\hline
\end{tabular}

aktivitas fisik dengan status gizi. Risiko malnutrisi meningkat sebesar 2.545 kali pada remaja yang beraktivitas fisik kurang.

Analisis multivariat menggunakan regresi logistik dilakukan untuk mengetahui variabel mana yang berpengaruh dominan terhadap status gizi remaja. Variabel yang dapat dilanjutkan dalam analisis multivariat adalah variabel yang memiliki nilai $\mathrm{p}<0,25$ pada uji bivariat yaitu kebiasaan konsumsi sayur, asupan karbohidrat, asupan lemak dan aktivitas fisik.

Dari Tabel 4 langkah pemodelan analisis multivariat, diketahui bahwa kebiasaan mengkonsumsi sayur $(p=0,005)$ dan aktivitas fisik $(p=0,016)$ merupakan variabel yang paling berpengaruh terhadap status gizi, hasil analisis determinan kedua variabel tersebut adalah disajikan pada Tabel 5 dimana nilai uji omnibus menunjukkan nilai signifikansi 0,001 , yang berarti penambahan variabel bebas berupa kebiasaan konsumsi sayur dan aktivitas fisik secara simultan dapat berpengaruh signifikan terhadap status gizi.

\section{PEMBAHASAN}

\section{Kebiasaan Konsumsi Sayur dan Status Gizi Remaja}

Kebiasaan konsumsi sayur remaja usia 16-17 tahun di Kota Pangkalpinang sebagian besar dalam kategori sering $(\geq 5$ kali seminggu). Sebanyak $152 \quad(67,3 \%)$ remaja dengan status gizi baik memiliki kebiasaan mengonsumsi sayuran yang sering dan $56(49,1 \%)$ remaja dengan status gizi buruk memiliki kebiasaan mengonsumsi sayuran yang jarang. Hasil analisis bivariat diperoleh nilai $\mathrm{p}$ sebesar 0,005 yang menunjukkan adanya hubungan yang signifikan antara kebiasaan konsumsi sayur dengan status gizi. Risiko malnutrisi meningkat secara signifikan sebesar 1.946 kali pada remaja yang memiliki kebiasaan konsumsi sayur yang kurang. Hasil ini sejalan dengan penelitian Arza \& Sari (2021) dimana terdapat hubungan positif antara frekuensi konsumsi sayur dengan status gizi remaja. Remaja yang tidak pernah makan sayur cenderung mengalami obesitas dibandingkan dengan remaja yang rutin mengkonsumsi sayur (Yang et al., 2021).

Konsumsi sayur dapat menurunkan obesitas karena kandungan seratnya yang memberikan rasa kenyang sehingga diduga dapat mengurangi asupan lemak dan energi dari makanan (Herzer, et al., 2011). Penyakit degeneratif seperti hipertensi, diabetes mellitus dan penyakit jantung koroner dapat dikurangi dengan mengkonsumsi sayur dan buah. World Health Organization, (2010) merekomendasikan konsumsi sayur dan buah setiap hari sebanyak 400g/hari sebagai sumer serat dan untuk memenuhi kebutuhan 
Tabel 5

Hasil Analisis Determinan

\begin{tabular}{ccccccc}
\hline Variabel & B & Wald & $\begin{array}{c}\mathrm{p}- \\
\text { value }\end{array}$ & $\begin{array}{c}-2 \text { Log likeli- } \\
\text { hood }\end{array}$ & Uji Omnibus & $\begin{array}{c}\text { Nagelkerke R } \\
\text { square }\end{array}$ \\
\hline $\begin{array}{c}\text { Kebiasaan konsumsi sayur } \\
\text { Aktivitas fisik }\end{array}$ & 0.666 & 7.879 & 0.005 & 437.888 & 0.001 & 0.069 \\
\hline
\end{tabular}

zat gizi mikro. Kebutuhan harian ini dapat dipenuhi dengan mengonsumsi lima porsi sayur dan buah per hari.

\section{Kebiasaan Konsumsi Buah Dan Status Gizi Remaja}

Ketidakcukupan asupan makanan pada remaja usia sekolah salah satunya disebabkan karena kurang mengkonsumsi buah dan sayur. Remaja mudah dipengaruhi oleh lingkungan sosialnya seperti keluarga, sekolah dan teman sebaya yang dapat mempengaruhi kebiasaan makan termasuk jenis makanan yang dikonsumsi.Sebagian besar kebiasaan konsumsi buah pada remaja usia 16-17 tahun di Kota Pangkal Pinang berada pada kategori sering ( $\geq 5$ kali seminggu).

Data karakteristik orang tua responden juga menunjukkan bahwa pendapatan orang tua responden sebagian besar berada pada kategori tinggi $(89,1 \%)$. Namun dari hasil kuesioner FFQ, hampir separuh responden menyatakan bahwa buah tidak tersedia setiap hari di rumah (55\%). Hanya 47 responden yang menyatakan bahwa buah tersedia setiap hari. Hal ini dimungkinkan karena faktor kebiasaan dan akses ketersediaan buah dimana beberapa sekolah sudah mulai menyediakan kantin sehat di bawah pengawasan petugas kesehatan yang menyediakan buah segar, sehingga responden cenderung lebih sering mengkonsumsi buah di luar rumah.

Hasil analisis bivariat diperoleh pvalue 0,285 yang menunjukkan bahwa tidak ada hubungan yang signifikan antara kebiasaan konsumsi buah dengan status gizi. Hasil ini sejalan dengan penelitian pada 228 remaja dimana tidak ada hubungan yang signifikan antara kebiasaan konsumsi buah dengan status gizi. Kebiasaan konsumsi buah remaja dipengaruhi oleh banyak faktor, seperti paparan media, preferensi konsumsi buah dan dukungan teman sebaya, remaja yang kurang dukungan teman sebaya berisiko mengkonsumsi buah 2,4 kali lebih sedikit dari $2 \mathrm{x}$ sehari. Konsumsi buah pada remaja juga berhubungan dengan kebiasaan yang didapat dari teman.

\section{Asupan Gizi Dan Status Gizi Remaja}

Hasil penelitian menunjukkan bahwa hampir semua responden memiliki asupan karbohidrat yang cukup (91,8\%), namun asupan lemak $(74,4 \%)$, asupan protein $(97,4 \%)$ dan asupan serat $(97,4 \%) \mathrm{ku}-$ rang. Analisis bivariat menunjukkan bahwa tidak ada hubungan antara asupan energi, protein, asupan lemak dan asupan serat dengan status gizi. Walaupun tidak bermakna secara statistik, hasil analisis regresi logistic diperoleh bahwa semakin rendah asupan karbohidrat $(\mathrm{OR}=1.635)$ dan lemak 
$(\mathrm{OR}=1.358)$, maka risiko kejadian malnutrisi pada remaja usia 16-17 tahun akan semakin tinggi. Hasil penelitian ini sama dengan penelitian pada mahasiswi di Surakarta (Rinanti, 2014) yang menunjukkan bahwa tidak ada hubungan antara asupan zat gizi makro (protein, lemak, dan karbohidrat) dengan status gizi. Namun berdasarkan analisis didapatkan bahwa remaja dengan asupan karbohidrat dan energi yang cukup memiliki status gizi yang baik. Hal ini menunjukkan bahwa jika asupan karbohidrat dan energi tidak terpenuhi maka akan berpeluang lebih besar untuk tergolong dalam kategori gizi buruk.

\section{Aktivitas Fisik dan Status Gizi Remaja}

Aktivitas fisik merupakan gerakan yang dihasilkan oleh otot rangka dan membutuhkan pengeluaran energi (Word Health Organization, 2016). Aktivitas fisik ringan adalah segala sesuatu yang berhubungan dengan menggerakkan tubuh, aktivitas fisik sedang adalah gerakan tubuh yang menyebabkan pengeluaran energi yang cukup besar, dengan kata lain bergerak yang menyebabkan nafas menjadi sedikit lebih cepat dari biasanya, sedangkan aktivitas berat adalah gerakan tubuh yang menyebabkan pengeluaran energi yang cukup. banyak (membakar kalori) sehingga nafas jauh lebih cepat dari biasanya.

Berdasarkan uji bivariat menunjukkan bahwa terdapat hubungan yang signifikan antara tingkat aktivitas fisik dengan status gizi remaja $(p=0,016)$. Penelitian ini sejalan dengan Baja \& Rismayanthi (2019) yang menyatakan bahwa status gizi dan aktivitas fisik memiliki hubungan yang saling mempengaruhi pada anak sekolah. Saat melakukan aktivitas fisik, tubuh akan membutuhkan banyak energi, makanan yang dicerna dalam tubuh akan diubah menjadi glukosa dan diedarkan ke seluruh bagian sel untuk mendapatkan energi (Tappy \& Rosset 2019). Ketika aktivitas fisik seseorang tinggi dan energi dalam tubuhnya kurang, enzim lipase dalam sel lemak akan memecah gliserol dan asam lemak, serta melepaskannya ke sel sehingga simpanan lemak yang terkandung dalam jaringan adiposa akan berkurang (Astuti, 2013).

Aktivitas fisik memiliki pengaruh terhadap kejadian obesitas. Semakin sedikit waktu yang dihabiskan untuk melakukan aktivitas sedang dan berat, semakin besar peluang terjadinya obesitas (Swift et al., 2018; Robinson et al., 2021; He et al., 2021). Semakin banyak aktivitas maka semakin banyak pula kalori yang digunakan sehingga tubuh menjadi normal atau malah semakin kurus, namun jika aktivitas tidak cukup, tubuh cenderung menyimpan kalori berlebih sehingga menyebabkan kelebihan berat badan. Koca et al. (2017) menyatakan bahwa melewatkan sarapan dikaitkan dengan kelebihan berat badan/obesitas pada anak sekolah dan remaja, sementara konsumsi susu menunjukkan efek perlindungan

Kurangnya aktivitas fisik adalah faktor risiko utama keempat untuk kematian global yang menyebabkan sekitar 3,2 juta kematian (Rocha, 2015). Penurunan aktivitas fisik disebabkan oleh banyaknya waktu luang dan perilaku sedentary di tempat kerja dan di rumah (Lavie et al., 2019; Schuna et al., 2013; Teychenne et al., 2013). Rendahnya tingkat aktivitas fisik juga disebab- 
kan oleh meningkatnya penggunaan alat transportasi (Woodward \& Wild, 2020). Aktivitas fisik merupakan salah satu faktor yang mempengaruhi status gizi, status gizi seseorang juga nantinya akan tergantung pada penggunaan zat gizi yang dikonsumsi saat melakukan aktivitas (Basir \& Zarwan, 2019). Aktivitas fisik seseorang dapat dilihat dari jenis dan intensitas aktivitas yang dilakukan. Menurut Romadhoni et al. (2020) asupan energi yang berlebihan dan tidak diimbangi dengan pengeluaran energi yang seimbang akan menyebabkan kenaikan berat badan.

Faktor-faktor yang diteliti dalam penelitian ini hanya memberikan kontribusi sebesar $6.9 \%$ terhadap kejadian malnutrisi pada remaja, sedangkan sisanya dipengaruhi faktor-faktor lain yang tidak diteliti.

\section{KESIMPULAN}

Risiko malnutrisi meningkat secara signifikan sebesar 2.46 kali pada remaja dengan aktivitas fisik kurang $(p=0.016)$ dan meningkat sebesar 1.94 kali pada remaja dengan kebiasaan konsumsi sayur yang kurang $(p=0.005)$. Semakin rendah asupan karbohidrat $(\mathrm{OR}=1.635)$ dan lemak $(\mathrm{OR}=1.358)$ maka risiko kejadian malnutrisi pada remaja usia 16-17 tahun akan semakin tinggi, tetapi tidak bermakna secara statistik ( $p=0.230 ; p=0.259)$. Keterbatasan dalam penelitian ini ada beberapa faktor perancu lainnya yang dapat mempengaruhi status gizi remaja yang tidak diteliti seperti riwayat penyakit infeksi, pola makan keluarga, besaran uang saku, pengetahuan remaja dan orang tua, faktor sosial budaya, faktor ekonomi dan lainnya yang kemungkinan dapat mempengaruhi status gizi remaja.

Pihak sekolah bekerja sama dengan orang tua siswa dan tenaga kesehatan untuk memberikan pendidikan gizi tentang makanan seimbang dan aktivitas fisik, sehingga siswa dapat mengubah perilaku kesehatannya menjadi lebih baik. Keluarga dan masyarakat perlu mendapat edukasi tentang pentingnya dukungan keluarga terhadap status gizi remaja, dukungan dapat berupa penyediaan sayur dan buah dirumah dan mendukung kebiasaan konsumsi makanan yang sehat

\section{DAFTAR PUSTAKA}

Abizanda, P., López, M. D., García, V. P., de Dios Estrella, J., da Silva González, Á., Vilardell, N. B., \& Torres, K. A. (2015). Effects of an oral nutritional supplementation plus physical exercise intervention on the physical function, nutritional status, and quality of life in frail institutionalized older adults: the ACTIVNES study. Journal of the American Medical Directors Association, 16(5), 439-e9. https://doi.org/10.1016/ j.jamda.2015.02.005

Arza, P. A., \& Sari, L. N. (2021). Hubungan konsumsi sayur dan buah dengan status gizi pada remaja di SMP Kabupaten Pesisir Selatan. Jurnal Kesehatan Kusuma Husada, 136-141. https://doi.org/10.34035/ jk.v12i2.758

Astuti, Y. T. (2013). Hubungan Asupan Makronutrien dan Kadar Hemoglobin dengan Aktivitas Fisik pada Remaja Putri di Asrama SMA MTA Surakarta (Doctoral dissertation, Universitas Muhammadiyah Surakarta). http://eprints.ums.ac.id/23493/

Baja, F. R., \& Rismayanthi, C. (2019). Hubungan Tingkat Pengetahuan Diet dan Aktivitas Fisik Terhadap Status Gizi Pada Siswa Sekolah Menengah Atas. MEDIKORA, 18 (1), 1-6. http://dx.doi.org/10.21831/ medikora.v18i1.29189 
Basir, H., \& Zarwan, Z. (2019). Tinjauan Status Gizi Siswa SMPN 10 Sijunjung Kecamatan Kamang Baru Kabupaten Sijunjung. Jurnal $J P D O, 2(1), 74-77$. http://jpdo.ppj.unp.ac.id/ index.php/jpdo/article/view/194

Camilo, B. D. F., Resende, T. I. M., Moreira, É. F. A., \& Damião, R. (2018). Sedentary behavior and nutritional status among older adults: a meta-analysis. Revista Brasileira de Medicina do Esporte, 24, 310-315. https:// doi.org/10.1590/1517869220182404183390

Emilia \& Cilmiyati, R. (2020). Pengaruh Konseling Gizi, Aktifitas Fisik, dan Asupan Makanan Terhadap Penurunan Berat Badan Remaja SMA yang Kegemukan. Pontianak Nutrition Journal (PNJ), 3(1), 6-12. https:// doi.org/10.30602/pnj.v3i1.624

Hargreaves, D., Mates, E., Menon, P., Alderman, H., Devakumar, D., Fawzi, W., \& Patton, G. C. (2021). Strategies and interventions for healthy adolescent growth, nutrition, and development. The Lancet. https:// doi.org/10.1016/S0140-6736(21)01593-2

He, M., Xian, Y., Lv, X., He, J., \& Ren, Y. (2021). Changes in body weight, physical activity, and lifestyle during the semi-lockdown period after the outbreak of COVID-19 in China: an online survey. Disaster medicine and public health preparedness, 15(2), e23-e28. http://doi.org/10.1017/dmp.2020.237

Herzer, M., Zeller, M. H., Rausch, J. R., \& Modi, A. C. (2011). Perceived Social Support and Its Association With Obesity-Specific HealthRelated Quality of Life. Journal of Developmental \& Behavioral Pediatrics, 32(3), 188$195 . \quad$ http://doi.org/10.1097/ dbp.0b013e318208f576

Hussain, A., Mahawar, K., Xia, Z., Yang, W., \& ElHasani, S. (2020). Obesity and mortality of COVID-19. Meta-analysis. Obesity research \& clinical practice, 14(4), 295. https:// dx.doi.org/10.1016\%2Fj.orcp.2020.07.002

Kordas, K., Burganowski, R., Roy, A., Peregalli, F., Baccino, V., Barcia, E., \& Queirolo, E. I. (2018). Nutritional status and diet as predictors of children's lead concentrations in blood and urine. Environment international, 111, 43-51. https://doi.org/10.1016/ j.envint.2017.11.013

Kurdanti, W., Suryani, I., Syamsiatun, N. H., Siwi, L. P., Adityanti, M. M., Mustikaningsih, D.,
\& Sholihah, K. I. (2015). Faktor-faktor yang mempengaruhi kejadian obesitas pada remaja. Jurnal Gizi Klinik Indonesia, 11(4), 179190. http://dx.doi.org/10.22146/ijen.22900

Lavie, C. J., Ozemek, C., Carbone, S., Katzmarzyk, P. T., \& Blair, S. N. (2019). Sedentary behavior, exercise, and cardiovascular health. Circulation research, 124(5), 799$815 . \quad$ https://doi.org/10.1161/ CIRCRESAHA.118.312669

Lenne, R. L., Joyal-Desmarais, K., Jones, R. E., Huelsnitz, C. O., Panos, M. E., AusterGussman, L. A., \& Simpson, J. A. (2019). Parenting styles moderate how parent and adolescent beliefs shape each other's eating and physical activity: Dyadic evidence from a cross-sectional, US National Survey. Journal of Experimental Social Psychology, 81, 76-84. https://doi.org/10.1016/ j.jesp.2018.06.003

Mead, E., Brown, T., Rees, K., Azevedo, L. B., Whittaker, V., Jones, D., \& Ells, L. J. (2017). Diet, physical activity and behavioural interventions for the treatment of overweight or obese children from the age of 6 to 11 years. Cochrane Database of Systematic Reviews, (6). https:// doi.org/10.1002/14651858.CD012651

Rinanti, O. S. (2014). Hubungan Asupan Zat Gizi Makro dan Pengetahuan Gizi Seimbang dengan Status Gizi Siswa-Siswi di SMP Muhammadiyah 1 Kartasura (Doctoral dissertation, Universitas Muhammadiyah Surakarta). http://eprints.ums.ac.id/31217/

Robinson, E., Boyland, E., Chisholm, A., Harrold, J., Maloney, N. G., Marty, L., \& Hardman, C. A. (2021). Obesity, eating behavior and physical activity during COVID-19 lockdown: A study of UK adults. Appetite, 156, 104853. j.appet. 2020.104853

Rocha, E. (2015). Physical inactivity: preventable risk factor of cardiovascular disease. In Prevention of Cardiovascular Diseases (pp. 49-58). Springer, Cham. https:// doi.org/10.1007/978-3-319-22357-5_6

Romadhoni, S. T., Sumbayak, E. M., \& Dewajanthi, A. M. (2020). Hubungan Aktivitas Fisik dan Perilaku Makan dengan Status Gizi Pelajar Sekolah Dasar Islam Al-Falaah Ciputat. Jurnal Kedokteran Meditek, 26(2), 7783. https://doi.org/10.36452/ 
doi.org/10.1113/JP278246

Schuna, J. M., Johnson, W. D., \& Tudor-Locke, C. (2013). Adult self-reported and objectively monitored physical activity and sedentary behavior: NHANES 20052006. International Journal of Behavioral Nutrition and Physical Activity, 10(1), 1-12. https://doi.org/10.1186/1479-5868-10-126

Schwarzenberg, S. J., Georgieff, M. K., Daniels, S., Corkins, M., Golden, N. H., Kim, J. H., \& Magge, S. N. (2018). Advocacy for improving nutrition in the first 1000 days to support childhood development and adult health. Pediatrics, 141(2). https:// doi.org/10.1542/peds.2017-3716

Swift, D. L., McGee, J. E., Earnest, C. P., Carlisle, E., Nygard, M., \& Johannsen, N. M. (2018). The effects of exercise and physical activity on weight loss and maintenance. Progress in cardiovascular diseases, 61(2), 206-213. https://doi.org/10.1016/ j.pcad.2018.07.014

Tappy, L., \& Rosset, R. (2019). Health outcomes of a high fructose intake: the importance of physical activity. The Journal of physiology, 597(14), 3561-3571. https://
Teychenne, M., \& York, R. (2013). Physical activity, sedentary behavior, and postnatal depressive symptoms: a review. American journal of preventive medicine, 45(2), 217227. j.amepre.2013.04.004 https://doi.org/10.1016/

WHO. (2010). Global Recommendation on Physical Avtivity for Health. WHO Press : Geneva, Switzerland.

WHO. (2016). Obesity and Overweight. https:// www.who.int/news-room/fact-sheets/detail/ obesity-and-overweight

Woodward, A., \& Wild, K. (2020). Active transportation, physical activity, and health. In Advances in transportation and health (pp. 133-148). Elsevier. https:// doi.org/10.1016/B978-0-12-819136$1.00005-\mathrm{X}$

Yang, S., Zhang, X., Feng, P., Wu, T., Tian, R., Zhang, D., \& Jia, P. (2021). Access to fruit and vegetable markets and childhood obesity: a systematic review. Obesity reviews, 22, e12980. https://doi.org/10.1111/ obr. 12980 